\title{
Comparison between Phage-ELISA and Phage Dot-Blot Assay Methods for the Detection of Hepatitis B Surface Antigen and its Antibodies in Human Serum
}

\author{
Geok Hun $\operatorname{Tan}^{1, *}$ and Wen Siang $\operatorname{Tan}^{2}$ \\ ${ }^{1}$ Department of Agriculture Technology, Faculty of Agriculture, Universiti Putra Malaysia, 43400 UPM, \\ Serdang, Selangor, Malaysia \\ ${ }^{2}$ Department of Microbiology, Faculty of Biotechnology and Biomolecular Sciences, Universiti Putra Malaysia, \\ 43400, Serdang, Selangor, Malaysia
}

\begin{abstract}
A modified phage-enzyme link immunosorbent assay (phage-ELISA) and a phage dot-blot assay specific for hepatitis B surface antigen ( $\mathrm{HBsAg}$ ) and its antibody were developed by using phage display technology. The phageELISA and phage dot-blot assays enabled to detect HBsAg and anti-HBsAg in human sera, and compatible to commercial detection kit. The fusion phages were immobilized onto microtiter plate wells and nitrocellulose membrane sheets, then blocked with 10\% milk diluent, and added with human serum at dilution of 1:5000. The absorbance at 405 $\mathrm{nm}$ was determined once the colour changes formed. The same human serum also applied on the commercial diagnostic kit for comparison. The statistical analysis was carried out using ANOVA and T Test (LSD) for variable comparison between phage-ELISA and phage dot-blot assays. Based on these studies, the phage-ELISA was found to be more sensitive compared to phage dot-blot assay as the detection of $\mathrm{HBsAg}$ in human sera was about $80 \%$ as compared to $51.7 \%$ by using phage dot-blot assay. Meanwhile, the sensitivity for detection of anti-HBsAg by using phage-ELISA was slightly higher which showed about $83.3 \%$. However, the sensitivity of the assay was dropped almost half when using phage dot-blot assay. Therefore, they are practical to be used as a reliable alternative way for the detection HBsAg and its antibody in human sera.
\end{abstract}

Keywords: HBsAg, phage-ELISA, phage dot-blot assay, human sera.

\section{INTRODUCTION}

Hepatitis B virus (HBV) is one of the most important causes of liver disease in the world. The spectrum of HBV-associated hepatitis ranges from acute to chronic infection, to cirrhosis and to hepatocellular carcinoma. About $95 \%$ of infected neonates and $50 \%$ of infected young children will become chronically infected [1]. In constantly, only $5 \%$ to $10 \%$ of immunocompetent adults infected with HBV developed chronic hepatitis [2]. The virus is transmitted by blood and body secretion including semen, saliva, tears and ascetic fluid contaminated with blood [2].

Hepatitis B surface antigen (HBsAg) is the first virological marker to appear in the blood circulation after a person is infected with HBV [3]. It can be found in filamentous or spherical in addition of virions [4]. HBsAg can be detected with available assay around 6 to 8 weeks after the infection. Normally, anti-HBsAg is not detectable when HBsAg is also present. These neutralizing antibodies are important in the prevention of viral infection [5]. They are detectable in the patient

\footnotetext{
*Address correspondence to this author at the Department of Agriculture Technology, Faculty of Agriculture, Universiti Putra Malaysia, 43400 UPM, Serdang, Selangor, Malaysia; Tel: 03-89474893; Fax: 03-89381015;

E-mail: geok_hun@upm.edu.my, tangeokhun@gmail.com
}

who has recovered from acute hepatitis $B$ and also in people immunized with HBV vaccine. A serum level 10 $\mathrm{mIU} / \mathrm{ml}$ of anti-HBsAg has been proposed to be the lowest limit for protection [6].

Determination of $\mathrm{HBsAg}$ and anti-HBsAg level in a blood serum sample is carried out commonly by immunoassay and dot-blot using antibody-phage interaction. In this phage-ELISA reaction, the capture of HBsAg and it's antibody in the human serum samples were bound to the fusion phages derived from phage display technology [7] [8] which immobilized previously on the microtiter plate wells forming a detectable sandwich complex, which induced colour production. Meantime, the dot-blot assay was established by dropping a spot of fusion phages onto a strip of nitrocellulose membrane and drying by sucking using vaccum pump. The strips were blocked and the capture of HBsAg and it's antibody in the serum samples were determined by its corresponding antibody. A positive reaction was often surrounded by a halo of dark purple colour, and it is clearly contrasted with the smaller, weak spots given by negative samples. Application of phage-ELISA and phage dot-blot hopes to be an alternative detection probe for hepatitis $B$ infection in the future. 


\section{MATERIALS AND METHODS}

\section{Fusion Phages and Human Serum Samples}

Construction of fusion T7-HBsAg ${ }_{111-156}$ phages have been described previously [8] according to Novagen, USA manufacturer. Recombinant M13 bearing ETGAKPH peptide was selected from disulfide constrained heptapeptide phage display library, which described [7] according to New England Biolabs, USA manufacturer. Clinical human serum samples were obtained from General Hospital of Kuala Lumpur, which left over from routine screening were used anonymously.

\section{Detection of HBsAg and Anti-HBsAg in Serum Samples by Phage Dot-Blot Assay}

Nitrocellulose membrane sheets $(0.45 \mu \mathrm{m}$, Osmonic, USA) were placed on dot-blot apparatus (Bio-rad, USA) which connected to vaccume pump. The fusion M13 bearing ETGAKPH peptide phages $\left(1.0 \times 10^{10} \mathrm{pfu} / \mathrm{ml}, 5 \mu \mathrm{l}\right)$ were blotted onto the membrane and allowed to air-dry for 15 minutes. The membranes were then blocked with milk diluent $(10 \%$, $\mathrm{KPL}, \mathrm{USA})$ for 2 hours at room temperature and washed with Phosphate Buffer Saline [PBS; $\mathrm{K}_{2} \mathrm{HPO}_{4}$ $\left.(20 \mathrm{mM}), \quad \mathrm{KH}_{2} \mathrm{PO}_{4} \quad(5 \mathrm{mM}), \quad \mathrm{NaCl} \quad(150 \mathrm{mM})\right]$ supplemented with $0.05 \%$ Tween 20 (PBST). Serum samples were diluted 1:5000 in PBS and incubated for 1 hour at room temperature. The membranes were washed three times with PBST and incubated for another hour with alkaline phosphatase conjugated anti-human $\operatorname{lgG}$ immunoglobulin (Chemicon, USA) diluted 1:5000 in PBS. Membranes were then washed and the immunocomplexes were revealed by substrate solution. On another hand, detection of anti-HBsAg in serum samples also followed the same steps, except using different phages for blotting. The strips were dried and examined, and the results expressed as a colorimetric reaction and densitometry analysis.

\section{Detection of Serum HBsAg and its Antibody by Phage ELISA}

Fusion phages [M13 bearing peptide and T7$\left.\mathrm{HBsAg}_{111-156}\left(1.0 \times 10^{10} \mathrm{pfu} / \mathrm{ml} ; 100 \mu\right)\right]$ were immobilized onto microtiter plate wells (flat bottom, Coastar, USA) overnight at $4{ }^{\circ} \mathrm{C}$, respectively. Free binding site of phages were blocked with milk diluent $(10 \%, \mathrm{KPL}, \mathrm{USA})$ for 2 hours and then washed three times with Tris Buffer Saline [TBS; Tris- $\mathrm{HCl}(50 \mathrm{mM}$, $\mathrm{pH} 7.5), \mathrm{NaCl}(150 \mathrm{mM})$ ] supplemented with $0.05 \%$ of Tween 20 (TBST), five minutes for each washing. The wells were then added with serum $\mathrm{HBsAg}$ diluted 1:5000 in TBS for 1 hour at room temperature. The plate wells were washed 6 times with TBST followed by anti-human IgG conjugated to alkaline phosphatase [1:5000; Chemicon, USA]. After 1 hour incubation, unbound antibodies were washed off with TBST and the substrate $p$-nitro phenyl phosphate (PNPP, Pierce, USA) was added. The absorbance at $405 \mathrm{~nm}$ was determined in a microtiter plate reader (Model 550, BioRad, USA) after 15 to 30 min of incubation at room temperature. These serum samples were applied on commercial SD HBsAg ELISA 3.0 and Anti-HBs ELISA 3.0 (Standard Diagnostics, Korea) in order to compare the detection efficiency of newly established phageELISA. Fusion M13 phage was used for detection of serum HBsAg while its antibody was detected by T7-

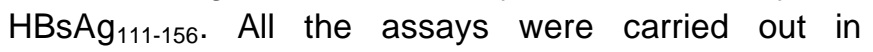
triplicates for each serum sample. The statistic analysis was carried out using ANOVA and T Test (LSD) for variable comparison between phage dot-blot assays and phage-ELISA.

\section{RESULTS AND DISCUSSION}

A phage dot-blot assay was established by immobilizing fusion phages, either T7-HBsAg ${ }_{111-156}$ or the phage carrying the ETGAKPH sequence on nitrocellulose membrane. Human HBV positive serum samples were added to interact with immobilized phages. An example of the colorimetric reaction using phage dot-blot assay is shown in Figure $\mathbf{1 a}$ and interpreted in Figure $\mathbf{1 b}$ by densitometry analysis. Fifteen human serum samples HBV positive were applied to nitrocellulose membrane which had been blotted with fusion phage M13. This phage is believed to have binding capability toward HBsAg in the sera [7]. Beside that, the interaction of fusion T7-HBsAg $111-156$ with anti-HBsAg also showed a similar results which can be viewed in Figures $\mathbf{2 a}$ and $\mathbf{2} \mathbf{b}$. The positive immunocomplexes reactions were revealed by formation of a halo dark purple colour. The control using $10 \%$ milk diluent showed a clear discrimination between positive and negative results.

In this study, fusion M13 phage was used to detect HBsAg particles in the sera, while bacteriophage T7$\mathrm{HBsAg}_{111-156}$ was used to detect anti-HBsAg. According to immunological study, HBsAg can be detected as the first marker to appear in an acute infection [8]. The present of anti-HBsAg may occurred when HBsAg no longer in the blood circulation. However, in some serious chronic cases, HBsAg and its antibody may occur at the same time [8]. So, HBsAg and anti-HBsAg 


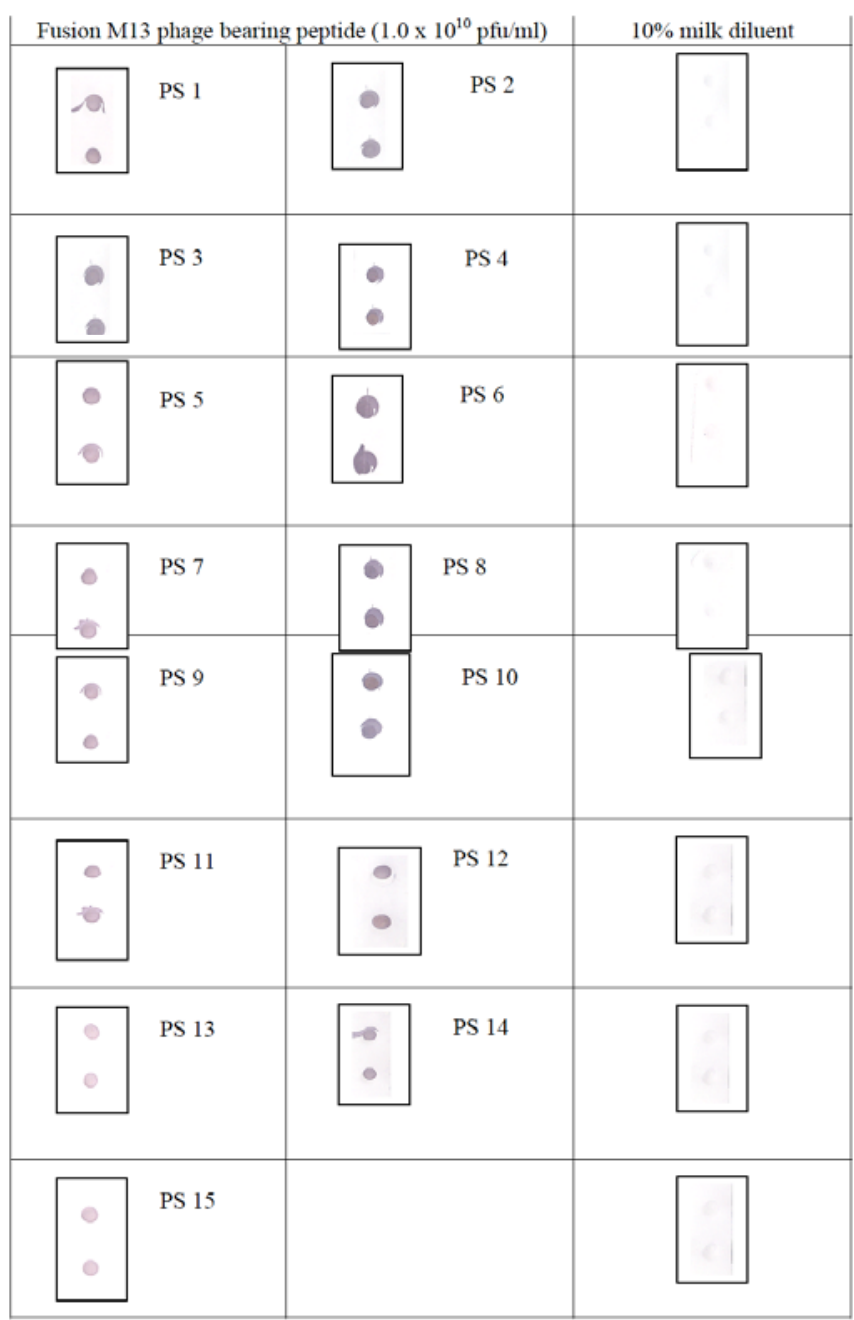

a

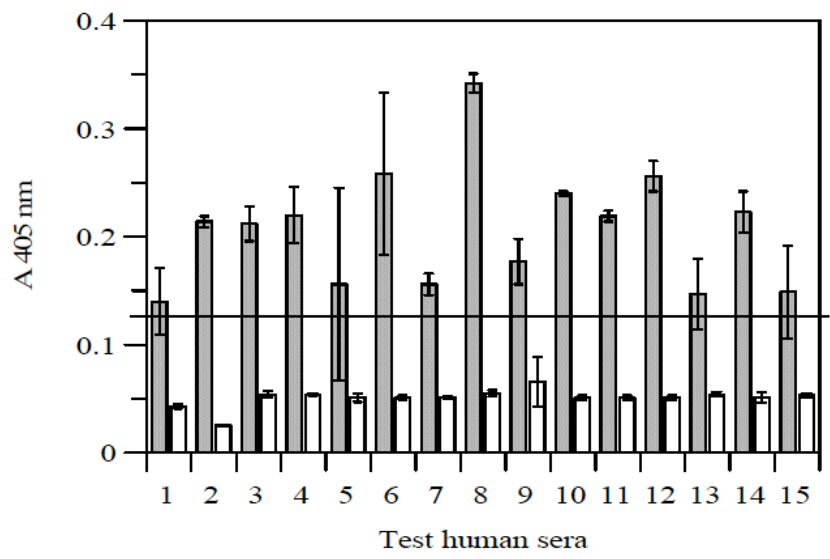

Human sera $\square$ Milk diluent

b

Figure 1: (a): Detection of HBsAg in human serum samples with fusion phage M13 bearing peptide ETGAKPH via dot-blot assay. The fusion phage were blotted in triplicates and added with human serum samples. Then, human AP-conjugated serve as secondary antibody and the PNPP substrate were used to confirm the detection of HBsAg. The fusion phage was substituted with $10 \%$ milk diluent for the negative controls, which did not show significant results.

(b): Densitometric analysis of fusion M13 phage bearing peptide for detection of HBsAg in human sera by dot-blot assay. The straight line across the figure is cut-off point. Assays were performed in triplicate and the error bars represent the standard deviation from the arithmetic mean. 


\begin{tabular}{|c|c|c|c|c|}
\hline \multicolumn{4}{|c|}{ Recombinant T7-HBsAg $111-156\left(1.0 \times 10^{10} \mathrm{pfu} / \mathrm{ml}\right)$} & $10 \%$ milk diluen \\
\hline $\begin{array}{r}\bullet \\
\Rightarrow\end{array}$ & PS 1 & e & PS 2 & 6 \\
\hline • & PS 3 & a & PS 4 & ( \\
\hline • & PS 5 & a & PS 6 & 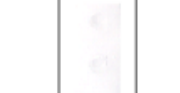 \\
\hline - & PS 7 & • & PS 8 & 8 \\
\hline - & PS 9 & $\bullet$ & PS 10 & ( \\
\hline a & PS 11 & ? & PS 12 & 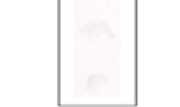 \\
\hline or & PS 13 & - & PS 14 & - \\
\hline • & PS 15 & & & 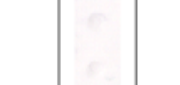 \\
\hline
\end{tabular}

a

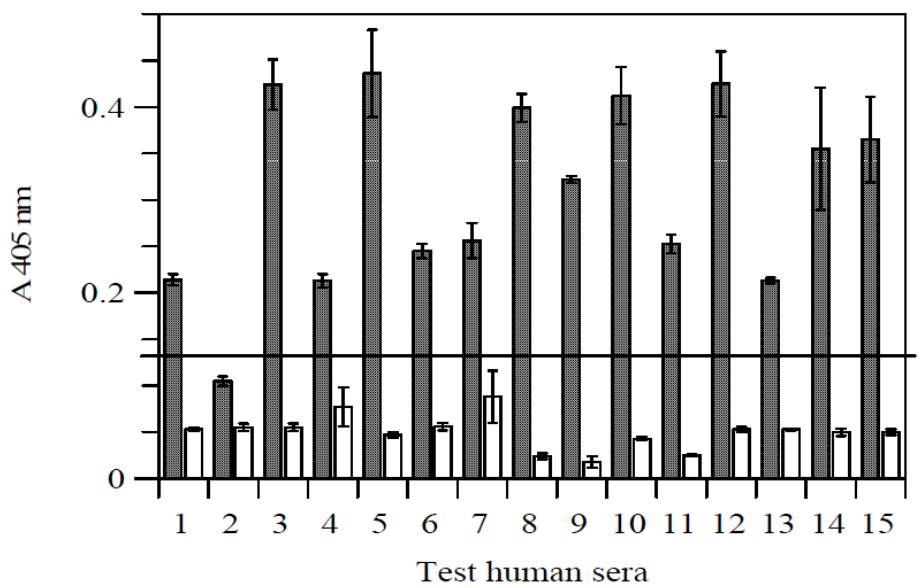

Human sera $\square$ Milk diluent

b

Figure 2: (a): Detection of anti-HBsAg in human serum samples with fusion T7-HBsAg111-156 phage via dot-blot assay. The recombinant phage were blotted in triplicates and added with human serum samples anti-HBsAg positive. Then, human APconjugated antibody and the PNPP substrate were added to determine the detection of anti-HBsAg. The fusion phage was substituted with $10 \%$ milk diluent for the negative controls, which did not show significant results.

(b): Densitometric analysis of fusion T7-HBsAg111-156 phage for detection of anti-HBsAg in human sera by dot-blot assay. The straight line across the figure is cut-off point. Assays were performed in triplicate and the error bars represent the standard deviation from the arithmetic mean.

tests are important method to evaluate acute or chronic HBV infection [9].
A phage-enzyme link immunosorbent assay (phageELISA) was applied for detection of HBsAg and its 


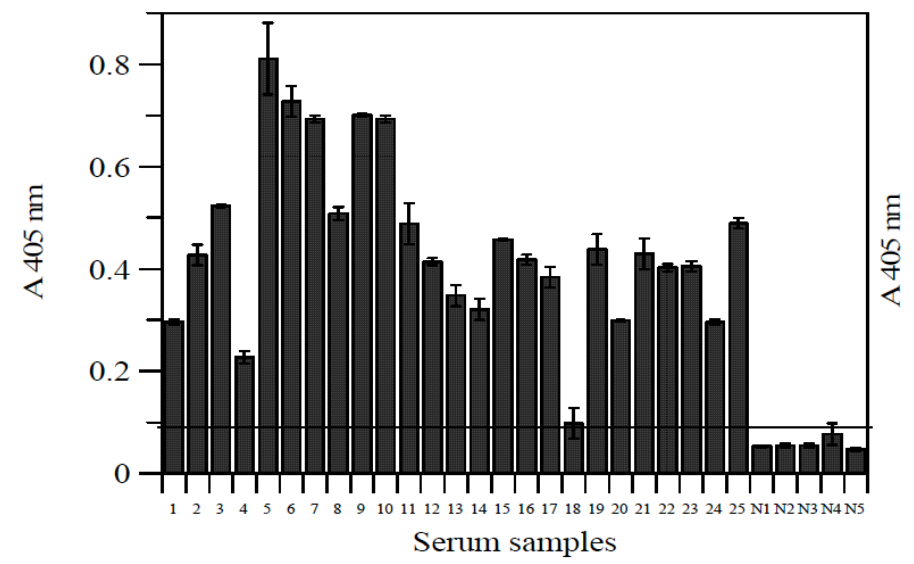

a

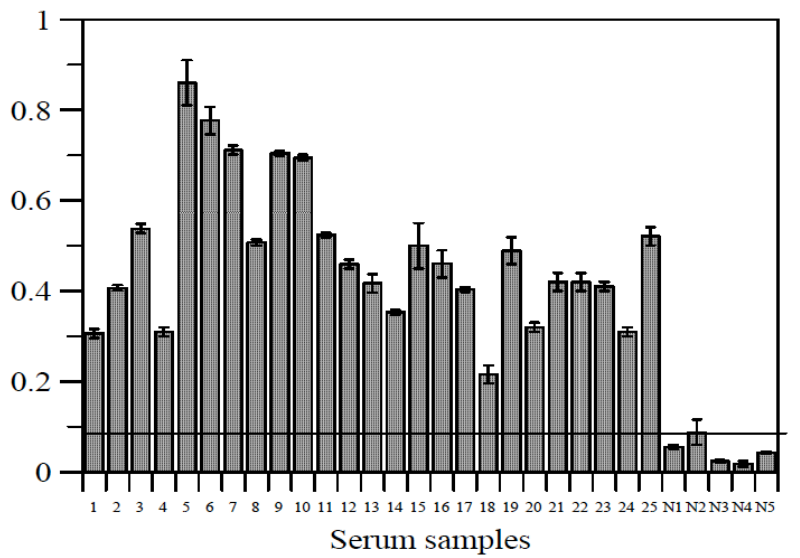

b

Figure 3: Detection of HBsAg in HBV positive and negative sera by fusion M13 phage bearing peptide and anti-HBsAg via phage-ELISA and commercial ELISA. (a) Microtiter plate were coated with fusion M13 phage and blocked with $10 \%$ milk diluent. The HBV positive and negative sera were added. After 1 hour of incubation, anti-human IgG AP conjugated was added followed by PNPP substrate. (b) The coated plate wells with anti-HBsAg were applied for the same sera and bound antibodies were developed by adding the PNPP substrate. The negative control was represented by N1 to N5. The straight line represents the cut-off point. Assays were performed in triplicates and the error bars represent the standard deviation from the arithmetic mean.

antibody in human sera. Fusion phages of M13 and T7$\mathrm{HBsAg}_{111-156}$ were first immobilized on the microtiter plate in order to capture HBsAg and anti-HBsAg in the HBV positive sera. From the previous study, the sensitivity of phage-ELISA was very high as it can captured HBsAg as low as $1 \mathrm{pg} / \mathrm{ml}$ [7]. This may due to the location of the phage binding which was located on the immunodominant region of $\mathrm{HBsAg}$. As a result, all 25 serum samples were tested positive to both the phage-ELISA (Figure 3a) and commercial available ELISA kit (SD HBsAg ELISA 3.0) (Figure 3b). There was no significantly different between anti-HBsAg used

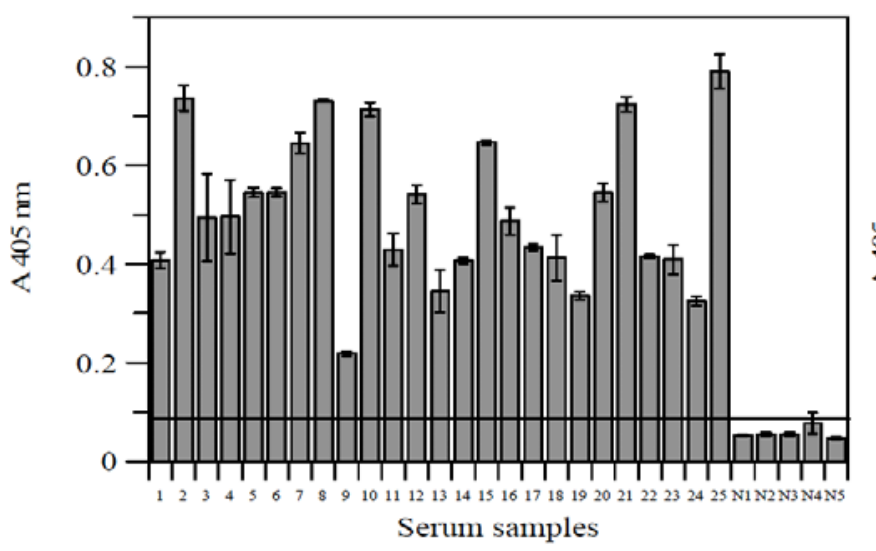

a in the commercial ELISA and fusion phage with the peptide sequence ETGAKPH.

On another hand, phage-ELISA assay of fusion T7HBsAg ${ }_{111-156}$ phage was also showed to be sensitive where the lowest concentration of anti-HBsAg could be detected was $0.25 \mathrm{mlU} / \mathrm{ml}$ [21]. This tight binding between $\mathrm{T7}$ phage and anti-HBsAg may be due to the physical and biological properties of T7 which capsid shell composed of 415 copies of gene 10 product that allow the high copy number of polypeptide to be displayed [10]. As a result, phage-ELISA based on fusion T7-HBsAg 111-156 phage also tested positive for

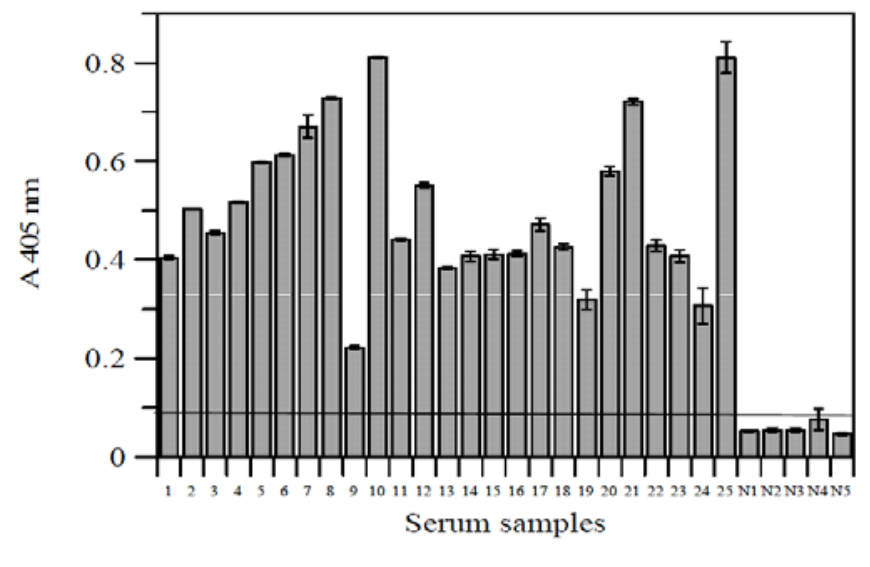

b

Figure 4: Detection of anti-HBsAg in the human serum samples by fusion T7-HBsAg111-156 versus HBsAg. (a). Microtiter wells are coated with fusion T7 phage and blocked with $10 \%$ milk diluent. HBV positive and negative samples were then added into the wells for 1 hour, followed by anti-human IgG AP conjugated for another hour. (b) The mircotiter plate wells were coated with HBsAg (commercial ELISA), and the sera used with recombinant T7 were applied on the wells. Bound antibodies were developed by adding the PNPP substrate. The negative control was represented by N1 to N5. The straight line across the figure is the cut-off point. Assays were performed in triplicates and the error bars represent the standard deviation from the arithmetic mean. 
anti-HBsAg in sera (Figure 4a), and there was also no significantly different between the surface antigen used in commercial kit and recombinant T7-HBsAg ${ }_{111-156}$ (Figure $\mathbf{4 b}$ ). None of five sera labeled as N1 to N5 showed any positive results.

The phage-ELISA and phage dot-blot were fixed into contingency table [11] and the sensitivity of both assays was compared (Tables $\mathbf{1}$ and 2). According to [11], the sensitivity of ELISA test is the probability that the test is positive when given to a group of patients with the disease. The formula sensitivity $=a /(a+c)$; where $a$ and $c$ are the number of true positive and false negative results, respectively. The specificity of ELISA test is the probability that the test be negative among patients who do not have the disease [11]. The formula for specificity $=d /(d+b)$; where $d$ and $b$ are the number of true negative and false positive results, respectively.

Based on these studies, the phage-ELISA was found to be more sensitive compared to phage dot-blot assay. From Table 1, the sensitivity for detection of
HBsAg in human sera was about $80 \%$ as compared to $51.7 \%$ by using phage dot-blot assay. Meanwhile, the sensitivity for detection of anti-HBsAg by using phageELISA was slightly higher which showed about $83.3 \%$. However, the sensitivity of the assay was dropped almost half when using phage dot-blot assay. However, the specificity of both assays for both detections was very low as showed in Tables $\mathbf{1}$ and $\mathbf{2}$. This may be due to the screen serum samples which obtained from hospital may contained some false positive serum which caused inconsistency of the specificity value.

As we know that $\mathrm{HBsAg}$ is one of the common immunological markers of HBV infection. A lot of studies on immunological methods have been done in order to develop a sensitive, relatively simple, low cost and quantitative analysis with high reproducibility ELISA method to detect HBsAg and its antibody in blood samples. In the past few years, most presently available ELISA method was depend on polyclonal and monoclonal antibodies which are isolated from sera of immunized animals or culture media of hybridomas as a recognition reagents. However, the production and

Table 1: Comparison of sensitivity and specificity for detection of HBsAg in human sera for clinical study by (a) phage-ELISA and (b) phage dot-blot. The absorbance of screen serum samples which used in phage-ELISA and phage-dot blot assay were considered positive if above the cut-off point $( \pm 0.1)$ and negative if below the cut-off point. The number of positive serum and negative serum were then tabulated into contingency table to get the sensitivity and specificity of the assays

\begin{tabular}{|c|c|c|}
\hline \multicolumn{2}{|c|}{ (a) Phage-ELISA } \\
\hline Positive & Negative & Total Results \\
\hline \hline$a$ & $b$ & $a+b$ \\
$(24)$ & $(6)$ & $(30)$ \\
\hline$c$ & $d$ & $c+d$ \\
$(6)$ & $(5)$ & $(11)$ \\
\hline$a+c$ & $b+d$ & $a+b+c+d$ \\
$(30)$ & $(11)$ & $(41)$ \\
\hline
\end{tabular}

Sensitivity: $80 \%$; Specificity: $45 \%$.

\begin{tabular}{|c|c|c|}
\hline \multicolumn{2}{|c|}{ (b) Phage dot-blot } \\
\hline Positive & Negative & Total Results \\
\hline \hline$a$ & $b$ & $a+b$ \\
$(31)$ & $(29)$ & $(60)$ \\
& & $c+d$ \\
$c$ & $d$ & $(66)$ \\
$(29)$ & $(37)$ & \\
& & $a+b+c+d$ \\
$a+c$ & $b+d$ & $(126)$ \\
\hline
\end{tabular}

Sensitivity: $51.7 \%$; Specificity: $56.1 \%$. 
Table 2: Comparison of sensitivity and specificity for detection of anti-HBsAg for clinical study using (a) phage-ELISA and (b) phage dot-blot. The absorbance of screen serum samples which used in phage-ELISA and dot-blot assay were considered positive if above the cut-off point $( \pm 0.1)$ and negative if below the cut-off point. The number of positive serum and negative serum were then tabulated into contingency table to get the sensitivity and specificity of the assays

\begin{tabular}{|c|c|c|}
\hline \multicolumn{2}{|c|}{ (a) Phage-ELISA } & Total Results \\
\hline Positive & Negative & $a+b$ \\
a & $b$ & $(30)$ \\
$(25)$ & $(5)$ & $c+d$ \\
c & $d$ & $(10)$ \\
$(5)$ & $(5)$ & $a+b+c+d$ \\
$(30)$ & $b+d$ & $(40)$ \\
\hline
\end{tabular}

Sensitivity: $83.3 \%$; Specificity: $50 \%$.

\begin{tabular}{|c|c|c|}
\hline \multicolumn{2}{|c|}{ (b) Phage dot-blot } \\
\hline Positive & Negative & Total Results \\
\hline \hline$a$ & $b$ & $a+b$ \\
$(24)$ & $(36)$ & $(60)$ \\
\hline$c$ & $d$ & $c+d$ \\
$(36)$ & $(30)$ & $(66)$ \\
\hline$a+c$ & $b+d$ & $a+b+c+d$ \\
$(60)$ & $(66)$ & $(126)$ \\
\hline
\end{tabular}

Sensitivity: $40 \%$; Specificity: $45 \%$.

purification of these antibodies are costly and timeconsuming, plus high risk of contamination. Recently, it has been shown that phage display technology has played important role in functional analysis of novel genes and proteomes. A wide range of proteins and protein domains have been displayed on the phage particles for carrying out directed evolution of molecules, such as stronger binder for the receptor [12], potentially novel enzyme [13], target receptors used in affinity selection includes the $S$ fragment of RNase [14], Streptavidin [15], complete virion of Newcastle disease virus (NDV) [16], HBcAg particles [17, 18], HBsAg [7] and antibody fragment specific for various antigens [19-21].

\section{CONCLUSION}

In this study, both phage-ELISA and phage dot-blot assays are similar enzyme immunoassays performed on different support substrates. In ELISA tests, antigen is usually bound to microtiter plates, whereas in the blot assay protein antigens are bound to nitrocellulose membrane sheets. The equipment involved with the dot-blot assay is less expensive than that used in
ELISA. Therefore, the dot-blot can be more economically advantageous than ELISA for the small diagnostic laboratory. However, ELISA may still provide a more versatile and accurate estimation of antigen than is derived from the dot-blot assay. This may be due to certain factors, such as (i) microplate wells are highly sensitive and specific used to detect substances in the biology samples; (ii) more objective readout, by using spectrophotometric reading OD of microtiter plate; (iii) time efficient, 96 well plates can be read in a few minutes and it is partially automated by using automatic pipetting stations. However, these both immunoassays are practical and offer a sensitive, specific, rapid, cheaper and reliable alternative way for the detection $\mathrm{HBsAg}$ and its antibody in human sera.

\section{ACKNOWLEDGEMENT}

The authors would like to thank the Ministry of Science, Technology and Innovation of Malaysia (MOSTI) for the grant support. Special thanks to the staffs in Virology Laboratory, Department of Microbiology, Faculty of Biotechnology and Biomolecular Sciences, Universiti Putra Malaysia, Serdang, Selangor, Malaysia for their help and support. 


\section{REFERENCES}

[1] Lee WM. Hepatitis B virus infection. New England J Med 1997; 337:1733-45. http://dx.doi.org/10.1056/NEJM199712113372406

[2] Stevent CE, Toy PT, Tong MJ, Taylor PE, Vyas GN, Nair PV, Gudavalli M, Krugman S. Perinatal hepatitis B virus transmission in the United States. J Am Med Assoc 1985; 253: $1740-5$.

http://dx.doi.org/10.1001/jama.1985.03350360066020

[3] Jung M-C, Pape GR. Immunology of hepatitis B infection. LANCET 2002; 2: 43-50. http://dx.doi.org/10.1016/S1473-3099(01)00172-4

[4] Seitz, R. Hepatitis B virus. Infus Ther Transfus Med 2000; 27 : 226-34. DOI: 10.1159/000025279.

[5] Tsitsilonis OE, Thrasyvoulides A, Balafas A, Voutsas JF, Papamichail M, Lymberi P. Serological detection of hepatitis $B$ viral infection by a panel of solid-phase enzyme-linked immunosorbent assays (ELISA). J Pharm Biomed Anal 2004; 34: 811-22.

http://dx.doi.org/10.1016/S0731-7085(03)00563-6

[6] Hollinger FB. Hepatitis B vaccines to switch or not to switch. J Am Med Assoc 1987; 257: 2634-6. http://dx.doi.org/10.1001/jama.1987.03390190112033

[7] Tan WS, Tan GH, Yusoff K, Seow HF. A phage-displayed cyclic peptide that interacts tightly with the immunodominant region of hepatitis $B$ surface antigen. Journal of Clinical Virology 2005; 34: 35-41. http://dx.doi.org/10.1016/j.jcv.2005.01.007

[8] Tan GH, Yusof K, Seow HF, Tan WS. Antigenicity and Immunogenicity of the Immunodominant Region of Hepatitis B Surface Antigen Displayed on Bacteriophage T7. J Med Virol 2005; 77: 475-80. http://dx.doi.org/10.1002/jmv.20479

[9] Hoofnagle TH, Dusheiko GM, Seeff LB, Jones EA, Waggoner JG, Bales ZB. Seroconversion from hepatitis B 'e' antigen to antibody in chronic type B hepatitis. Ann Intern Med 1981; 94: 744-8. http://dx.doi.org/10.7326/0003-4819-94-6-744

[10] Rosenberg A, Griffin K, Studier W, McCormick M, Berg J, Novy R, Mierendorf R. T7 Select phage display system: a powerful new protein display system based on bacteriophage T7. Novations Novagen Newsletter 1996; 6:1-6. DOI: 10.3390/molecules 19022481.

[11] Guyatt GH, Oxman AD, Ali M, William A, Mcllroy W, Pattersow C. Laboratory diagnosis of iron deficiency anemia: an overview. J Gen Intern Med 1992. 7: 145-53. http://dx.doi.org/10.1007/BF02598003
[12] Lowman HB, Bass SH, Simpson N, Wells JA. Selecting highaffinity binding proteins by monovalent phage display. Biochem 1991; 30: 10832-8. http://dx.doi.org/10.1021/bi00109a004

[13] Soumillion $P$, Jespers L, Bouchet M, Marchand-Brynaert J, Winter G, Fastrez J. Selection of beta-lactamase on filamentous bacteriophage by catalytic activity. J Mol Biol 1994; 237: 415-22. http://dx.doi.org/10.1006/jmbi.1994.1244

[14] Smith GP, Schultz DA, Ladbury JE. A ribonuclease S-peptide antagonist discovered with a bacteriophage display library. Gene 1993; 128: 37-42. http://dx.doi.org/10.1016/0378-1119(93)90150-2

[15] Devlin JJ, Panganiban LC, Devlin PE. Random peptide libraries. A source of specific protein binding molecules. Science 1990; 249: 404-6.

http://dx.doi.org/10.1126/science.2143033

[16] Ramanujam P, Tan WS, Nathan S, Yusoff K. Selection of peptide inhibitors that inhibit the replication of Newcastle disease virus. Arch Virol 2002; 147: 981-93. http://dx.doi.org/10.1007/s00705-001-0778-y

[17] Dyson MR, Germaschewski V, Murray K. Direct measurement via phage titer of the dissociation constants in solution of fusion phage-substrate complexes. Nucleic Acids Res 1995; 23:1531-5. http://dx.doi.org/10.1093/nar/23.9.1531

[18] Ho KL, Yusoff K, Seow HF, Tan WS. Selection of high affinity binding phages on hepatitis $\mathrm{B}$ core particles with a disulfide constrained phage display library. J Med Virol 2003; 69:2732.

http://dx.doi.org/10.1002/jmv.10266

[19] Barbas C, Kang A, Lerner R. and Benkovic S. Assembly of combinatorial antibody libraries on phage surfaces: the gene III site. Proc Nat Acad Sci USA 1991; 88: 7978-82. http://dx.doi.org/10.1073/pnas.88.18.7978

[20] Clackson T, Hoogenboom HR, Griffiths AD, Winter G Making antibody fragment using phage display libraries. Nature 1991; 352: 624-8.

http://dx.doi.org/10.1038/352624a0

[21] McCafferty J, Griffiths AD, Winter G, Chiswell DJ. Phage antibodies: filamentous phage displaying antibody variable domains. Nature 1990; 348: 552-4. http://dx.doi.org/10.1038/348552a0

\section{DOI: http://dx.doi.org/10.6000/1927-3037.2014.03.04.3}

(c) 2014 Tan and Tan; Licensee Lifescience Global.

This is an open access article licensed under the terms of the Creative Commons Attribution Non-Commercial License (http://creativecommons.org/licenses/by-nc/3.0/) which permits unrestricted, non-commercial use, distribution and reproduction in any medium, provided the work is properly cited. 